\title{
VALIDATION OF THE SAFETY ATTITUDES QUESTIONNAIRE (SHORT FORM 2006) IN MANAGEMENT STAFF OF CROATIAN HOSPITALS
}

\author{
Maša Bulajić ${ }^{1}$, Tonći Lazibat $^{2} \&$ Davor Plavec ${ }^{3}$
}

UDC / UDK: 614.253.83(497.5)

JEL classification / JEL klasifikacija: I11, I18

DOI: https://doi.org/10.22598/pi-be/2018.12.1. 55

Preliminary communication / Prethodno priopćenje

Received / Primljeno: Jule 4, 2017 / 4. srpnja 2017.

Accepted for publishing / Prihvaćeno za tisak: June 11, 2017 / 11. lipnja 2018.

\section{Summary}

Most healthcare organizations lack the ability to evaluate the safety of care they provide to their patients. Safety climate may be interpreted as the measurable part of safety culture.

Healthcare professionals' perception of the safety climate has been used as a tool to develop the instruments to measure patient safety climate in healthcare. Safety Attitudes Questionnaire 2006 Short Form (SAQ) has been considered a reliable and sensitive tool to assess safety attitudes. It has been used to explore the relationship between safety climate scores and patient outcomes and has also become the most commonly used self-reported psychometric questionnaire that measures safety attitudes in front-line workers.

SAQ has been proven to possess good psychometric properties also when translated. This study represents a national cross-sectional on-line survey about the safety attitudes of the management staff of Croatian hospitals, based on the SAQ. The aim of this study was to establish the validity of the SAQ translated to the Croatian language by evaluating its psychometric properties in a sample of the hospital management staff of Croatian hospitals.

\footnotetext{
${ }^{1}$ Maša Bulajić, M.D., M.Sc.Econ / Ph. D., Candidate, Marti Farm LLC, Zagreb, Croatia, E-mail: merkur3005@gmail.com

2 Tonći Lazibat, Ph. D., Full Professor, Faculty of Business and Economics, University of Zagreb, Croatia, E-mail: tlazibat@efzg.hr

3 Davor Plavec, M.D., Ph.D., Associate Professor, Faculty of Medicine, J.J. Strossmayer University of Osijek, Croatia, E-mail: plavec@bolnica-srebrnjak.hr
} 
Correlation between SAQ factors was comparable to that in SAQ studies in other countries. Correlation between SAQ factors was comparable to that in other SAQ studies. Yet, the overall score in Croatia was higher for most of the factors, with the exception of Stress Recognition. Along with the development of quality and safety in Croatian hospitals, future data on patient outcomes should allow for further validation studies, linking them with the SAQ-scores.

Key words: attitudes; Croatia; management, hospital; safety; Safety Attitude Questionnaire (SAQ).

\section{INTRODUCTION}

Safety and quality have been recognized as the priorities of utmost importance in healthcare systems worldwide. There have been numerous attempts to develop tools to evaluate and measure safety and quality. However, nearly all healthcare organizations lack the ability to evaluate the safety of care they provide to their patients (Pronovost, 2006).

Safety climate may be interpreted as the measurable part of the safety culture (Sexton, 2006), reflecting the perception of healthcare staff about the safety climate (Luiz, 2015). Healthcare professionals' perception of the safety climate has been used as a tool to develop the instruments to measure patient safety climate in healthcare. Qualitative studies regarding quality in healthcare and patient safety have been a subject of extensive research and are described in e.g. "Strategies for leadership: An Organizational Approach to Patient Safety", "Checklist for Assessing Institutional Resilience" (CAIR) and by Carthey (Carthey, 2001). Many studies describe quantitative research and their results (Burr, 2002; Sorra 2004; Weingart, 2004; Sexton, 2004; Sexton, 2006; European Society for Quality in Healthcare, 2010). The most widely used quantitative safety culture survey instruments were described and analysed in a comprehensive review of available studies published by the year 2005 (Colla, 2005). A comprehensive and sound value of quantitative studies such as the Veterans Administration Patient Safety Culture Questionnaire (VHA PSCQ), the Hospital Transfusion Service Safety Culture Survey (HTSSCS), the Hospital Survey on Patient Safety (HSOPS), and the Safety Attitudes Questionnaire (SAQ) stand out (Colla, 2005). These quantitative research methods are also recommended by the European Society for Quality in Healthcare - Office for Quality Indicators to be used in patient safety research (European Society for Quality in Healthcare, 2010).

SAQ has been considered a reliable and sensitive tool to assess safety attitudes. Only SAQ has been used to explore the relationship between safety climate scores and patient outcomes (Colla, 2005). SAQ has also become the most commonly used self-reported psychometric questionnaire that measures safety attitudes in front-line workers (Sexton, 2006). Originally, SAQ was developed from FMAQ - the Flight Management Attitudes Questionnaire (Helmreich, 1993) which had been designed to measure safety culture in aviation in the form of a human factors survey. The SAQ of today is a modification of the later developed ICUMAQ - Intensive Care Unit Management Attitudes Questionnaire (Sexton 2000, Pronovost 2005) 
SAQ is commonly used to assess healthcare professionals' attitudes in various clinical areas and settings (Zimmermann, 2013). SAQ has been proven to possess good psychometric properties also when translated. Apart from the English version (Sexton, 2006), SAQ was rigorously cross-culturally validated in a number of languages: Albanian (Gabrani, 2015), Arabic (Hamdan, 2013), Chinese (Lee, 2010), Dutch (Devriendt, 2012), English (Sexton, 2006), German (Hoffmann, 2009), Italian (Ngyen, 2015), Norwegian (Deilkås, 2008), Portugese (De Carvalho), Slovenian (Klemenc-Ketis, 2017), Swedish (Norden-Hagg, 2010), and Turkish (Kaya, 2010). The SAQ consists of 30-60 items which are measured on a 5-point Likert scale (Sexton, 2006). The first 6 validation and reliability studies were carried out by Sexton and affiliates in the US, UK and New Zealand (Sexton, 2006). Further conducted studies have confirmed strong psychometric properties of the SAQ as an instrument.

The aim of this study was to establish the validity of the translated version of the Safety Attitudes Questionnaire (SAQ; Hospital Version) by evaluating its psychometric properties in a sample of the hospital management staff of Croatian hospitals.

\section{METHODS}

\subsection{Study design}

This study represents a cross-sectional survey about safety attitudes of the management staff of Croatian hospitals. The study was performed between the beginning of September and the end of November 2016. The study was organized as an on-line survey using the SAQ short form - Croatian version. A link to the SAQ short form 2006 Croatian version was sent by e-mail together with a cover letter to general managers (GM) of the 61 hospitals that were listed on the Ministry of Health's publicly disclosed list to first inform the leadership of each hospital about a possible study to be conducted at their institution. The cover letter explained the aim of the study, confidentiality, anonymity, voluntary participation, with contacts of the principal investigator in case further information or explanation were needed. Every hospital's GM was asked to fill in the questionnaire from his/her professional point of view and to forward the invitation letter and the link to the questionnaire to the hospital's Quality Manager, Head Nurse and the managers of the clinical areas, since both the physicians and the nurses may have managerial duties and responsibilities at their respective positions. All the participants participated voluntarily.

By opening the link, the interviewed participants got the access to a questionnaire posted on the Google forms web application, which allowed for anonymity. The application was designed so that it would not allow submitting the questionnaire as long as all the questions were not answered. This however did not include the question regarding the name of the hospital, since full anonymity was promised to all who did not feel comfortable about disclosing their place of work. Since this challenge was presumed frequent, a question about the size of the hospital was asked to collect data for further planned analysis. Anonymity was judged important, as a no-blame culture has not yet been developed, and being afraid of being recognized would have affected the answers. 
Ultimately, it was up to the participants to decide whether or not they would disclose the name of the hospital. Presuming that a significant portion of the participants would prefer staying anonymous, additional questions, which had previously been agreed with the University of Texas experts, were included after the SAQ standard questionnaire. These included the size of the hospital, formal managerial education, gender, and years in service.

The first invitation letter to the GMs was sent on September $2^{\text {nd }}, 2016$. Data were collected on the web platform during a determined period of 75 days. A reminder was sent approximately 45 days after the first letter to all GMs, as the authors could not trace back where the answers came from, unless it was clearly indicated. Therefore, it made sense to resend all the letters to all the GMs.

As the study did not involve patients, the ethics committee's approval was not necessary. However, the largest Croatian hospital/University Hospital Center requested the study to be sent to their ethics committee (EC) for approval. The EC approved the study.

\subsection{Questionnaire}

The SAQ short form may be used as a reliable tool to measure safety attitudes among the personnel in the intensive care units, operating rooms, emergency departments, maternity wards, inpatient wards and ambulatory clinics, as well as in pharmacies (Deilkås, 2008). Also, it can be used among the primary healthcare staff like in the Netherlands (Devriendt, 2012) or Slovenia (Klemenc-Ketis, 2017). However, as no national quality standards have been developed for primary health care, and based on the results of a previous research on the national level (Žabica, 2014), it was decided that the attitudes of the primary health care staff were going to be left outside the scope of this study.

The SAQ short form 2006 is available online (https://med.uth.edu/chqs/surveys/ safety-attitudes-and-safety-climate-questionnaire/). Written permission to use SAQ for the first time in Croatia was obtained from the University of Texas in the summer of 2016, along with the guidelines on how to address the specific additional fields which are interesting in relation to the specificities of the Croatian healthcare system.

SAQ contains the items divided into 2 parts. The first part has six domains, divided as follows: Teamwork Climate (perceived quality of collaboration between staff), Satisfaction at Work (positivity about the work experience), Perception of Service and Hospital Management (approval of managerial action), Safety Climate (perceptions of a strong and proactive organizational commitment to safety), Work Conditions and Perceived Stress (perceived quality of the Intensive Care Unit work environment and logistical support - e.g. staffing, equipment) (Sexton, 2003). The response to each item follows a five-point Likert scale: disagrees completely (A), disagrees partially (B), neutral (C), agrees partially (D), agrees completely (E) and does not apply. The final score of the SAQ ranges between 0 and 100, with value 0 corresponding to the worst perceived 
safety climate and value 100 to the best. Scores of 75 and above are considered as positive (Sexton, 2003).

The second part contains data about the form of certification, professional position, years of experience, gender, age, formal education in management/healthcare leadership.

SAQ was translated to the Croatian language, using the World Health Organization's guidelines for linguistic validation (Process of translation and adaptation of instruments). Back-translation technique was used for the linguistic validation of our translation (Sperber, 2004). The SAQ short form 2006 was translated to Croatian by two independent native speakers, both experts in the field of medicine and in professional translation. For translation and adaptation of the titles and occupations which are not recognized in the Croatian healthcare, a bi-lingual Canadian expert educated and practicing in Croatia was consulted. Just as in the Italian version (Ngyen, 2015), some of the job titles were modified to reflect the job titles in Croatia. After reconciliation, a final Croatian translation version was sent to a Croatian born bi-lingual healthcare manager educated and working in the United States, blinded to the original questionnaire. To prove the equivalence, the back-translated version was then compared to the original English version. A team of three professionals specialized in quality of healthcare and a psychologist with experience in questionnaires performed a cognitive test on the final Croatian version.

\subsection{Subjects}

The questionnaire was sent to 61 hospital GMs. There were 16 of these hospitals that had implemented ISO 9001 certification at the level of the whole institution. This data is based on the results of the preliminary research that had been conducted by the first author of this paper beforehand, before the SAQ questionnaire was even initiated. One of these 16 hospitals also achieved a valid international accreditation certificate, and one hospital reported that the accreditation process was about to be completed. In addition, there were 7 hospitals who implemented the ISO 9001 in some of the units, 23 who did not implement ISO 9001 at all, and one hospital reported an ongoing ISO 9001 certification process. One hospital answered they would reply later, but never did.

Every Croatian hospital larger than 40 beds is obliged by law to employ a fulltime quality manager. It is however not self-explanatory that there would consequently be 61 full-time quality managers employed, as this position is often perceived as a side task that can be performed along with everyday clinical work.

The managers that participated in the study differed among the hospitals. In addition to the 36 SAQ translated questions, the participants were asked to report the following:

- Size of their hospital (number of beds);

- Name of the unit where they spend most of their working hours. This was important because some professionals do their tasks as e.g. hospital quality managers in addition to their clinical work, some are divided between units etc; 
- Gender;

- Years of experience;

- Their own formal education in healthcare management;

- Implementation of a recognized quality system (QS) in their hospital (yes, no);

- Their own opinion on QS implementation regarding reduction of costs in their hospital;

- Name of the hospital (voluntary)

\subsection{Response rate}

The questionnaire was sent to each of the 61 Croatian hospitals, out of which 49 hospitals replied. Unless specifically reported by the participants who answered the SAQ, it was not possible to trace the names of the receptive hospitals where the managers worked. By filling and submitting the web posted questionnaire, the participants were promised anonymity, to prevent possible blame.

\subsection{Data analysis}

Data analyses were performed using STATISTICA version 12 (StatSoft, Inc., OK, USA). Categorical variables were presented as numbers and proportions (\%). Quantitative variables were presented as mean and standard deviations (SD). Normality of the distributions was tested using Kolmogorov-Smirnov test. Confirmatory factor analysis was performed for the SAQ results. As the confirmatory factor analysis showed that there was no significant association of a single question (Q29) results with the hypothesized model (the Working Conditions factor) we redid the confirmatory factor analysis by moving this question to the Perception of Management factor as it had been in the original US SAQ. Cronbach alphas, item-to-item correlations and response distribution analysis was then calculated based on these new data and presented in the results. $\mathrm{P}<0.05$ was used as statistically significant for all analyses.

\section{RESULTS}

\subsection{Characteristics of subjects}

Invitation to participate in the survey was sent to 61 hospitals from all parts of Croatia. Employees from 49 hospitals answered.

The response rate in Croatia was $80 \%$ and is calculated at the hospital level. As a benchmark, the response rate was $60 \%$ for the neighboring Italy, where a study was performed on the staff of two hospitals (Ngyen, 2015). The response rate was higher for US, UK and New Zealand (Sexton, 2006), Norway (Deilkås, 2008), and Turkey (Kaya, 2010). The response rate for the Slovenian study (Klemenc-Ketis, 2017) was 57.1\%, but it 
implied the employment of one professional who was responsible for data collection in each of the participating primary healthcare organizations outside the working hours.

The response rate would have probably been higher in this study if we had decided to deliver the questionnaires personally. Yet, based on our experience and knowing the circumstances and the local culture, it was our decision to perform the study with as little personal influence as possible, thereby diminishing to the maximum a possible fear of answers being connected to the participants. Understanding that the no-blame culture has not been entirely accepted, an e-mail cover letter to the hospital GMs was chosen in combination with the anonymity-guaranteeing web platform for submitting and collecting the answers. Also, more than a decade ago, the authors of SAQ anticipated a migration to web-based data collection in the next several years, following the development of preferred means of communication (Sexton, 2003). It is important to mention that the design of our web-based platform allowed for no semi-filled questionnaires. It was possible to submit only the entirely filled questionnaires.

There were 105 Croatian hospital managers that answered the questionnaire, 68 women and 37 men during a period of 75 days.

Among those that answered, there were 36 managers with completed formal education in management/leadership in healthcare, and 63 without formal education (6 participants did not reply). The departments/units were: department of medicine and all other non-surgical departments $(n=33)$, surgery $(n=27)$, supportive departments (e.g. diagnostics, laboratories) $(n=7)$, psychiatry $(n=11)$, and board/management $(n=27)$.

Out of 105 respondents, there were 32 of them from the hospitals which obtained some form of quality certification.

According to the number of beds, the hospitals were divided in 4 sizes: $<500$ beds ( $\mathrm{n}$ of answers=69), 500-1000 beds ( $\mathrm{n}$ of answers $=8$ ), 1001-1500 beds ( $\mathrm{n}$ of answers=13), $>1500$ beds ( $n$ of answers $=15$ )

\subsection{Psychometric properties}

The confirmatory factor analysis for the hypothesized model showed that Q29 was not significantly associated with Working Conditions SAQ factor ( $\mathrm{p}=0.368$ ) so we recalculated the Perception of Management and Working Conditions factors, moving the Q29 from Working Conditions to Perception of Management just like in the original US SAQ. The confirmatory factor analysis done using the recalculated SAQ factors showed significant associations with all questions related to individual SAQ factors $(\mathrm{p}<0.01$ for all).

Internal consistency for SAQ was acceptable for the whole questionnaire (Cronbach alpha $=0.88$ ). For different factors, it was from 0.59 to 0.84 ( 0.59 for Teamwork Climate, 0.66 for Safety Climate, 0.84 for Job Satisfaction, 0.79 for Stress Recognition, 0.77 for Perceptions of Hospital Management, 0.80 for Perceptions of Unit Management, and 0.75 for Working Conditions). If Q2 were deleted from Teamwork Climate, Cronbach alpha would change to 0.83 . Also, if Q11 were deleted from Safety Climate, its Cronbach 
alpha would change to 0.82 . Therefore, the factors Teamwork Climate and Safety Climate showed poor and questionable internal consistency compared to the overall questionnaire, but the internal consistency of these two factors could have been significantly improved by excluding the two questions (Q2 and Q11).

All factors except Stress Recognition showed significant correlations with the overall SAQ score and other factors, Stress Recognition showing inverse correlations with other factors (insignificant for all except for Working Conditions) (Table 1).

Table 1: Inter-correlations between factors

\begin{tabular}{|l|c|c|c|c|c|c|c|}
\hline \multicolumn{1}{|c|}{ Safety factors } & (1) & (2) & (3) & (4) & (5) & (6) & (7) \\
\hline SAQ Overall (1) & 1.000 & 0.737 & 0.848 & 0.768 & $0.107^{*}$ & 0.804 & 0.705 \\
\hline Teamwork Climate (2) & & 1.000 & 0.678 & 0.546 & $-0.150^{*}$ & 0.464 & 0.516 \\
\hline Safety Climate (3) & & & 1.000 & 0.630 & $-0.145^{*}$ & 0.647 & 0.646 \\
\hline Job Satisfaction (4) & & & & 1.000 & $-0.123^{*}$ & 0.573 & 0.521 \\
\hline Stress Recognition (5) & & & & & 1.000 & $-0.077^{*}$ & -0.260 \\
\hline Perception of Management (6) & & & & & & 1.000 & 0.626 \\
\hline Working Conditions (7) & & & & & & & 1.000 \\
\hline
\end{tabular}

Note: All correlations are significant $(\mathrm{p}<0.05)$, except $\left({ }^{*}\right)$

Mean scores for the overall SAQ score and SAQ factors are presented in Table 2 in comparison with studies in other languages.

Table 2: Mean scores ( \pm standard deviation) of safety factors on 100-point scale of the study population and of characteristics of different groups

\begin{tabular}{|l|c|c|c|c|c|c|c|c|}
\hline $\begin{array}{l}\text { Safety } \\
\text { factors }\end{array}$ & $\begin{array}{c}\text { SAQ } \\
\text { Overall }\end{array}$ & $\begin{array}{c}\text { Teamwork } \\
\text { Climate }\end{array}$ & $\begin{array}{c}\text { Safety } \\
\text { Climate }\end{array}$ & $\begin{array}{c}\text { Job } \\
\text { Satisfac- } \\
\text { tion }\end{array}$ & $\begin{array}{c}\text { Stress } \\
\text { Recogni- } \\
\text { tion }\end{array}$ & $\begin{array}{c}\text { Percep- } \\
\text { tion of } \\
\text { Manage- } \\
\text { ment } \\
\text { Hospital }\end{array}$ & $\begin{array}{c}\text { Percep- } \\
\text { tion of } \\
\text { Manage- } \\
\text { ment } \\
\text { Unit }\end{array}$ & $\begin{array}{c}\text { Working } \\
\text { Conditions }\end{array}$ \\
\hline Croatia & $70.3 \pm 9.5$ & $73.2 \pm 11.6$ & $67.9 \pm 12.8$ & $82.0 \pm 14.6$ & $62.6 \pm 22.6$ & $65.8 \pm 15.4$ & $64.2 \pm 14.5$ & $69.6 \pm 21.0$ \\
\hline Albania & & & & & & & & \\
\hline Brazil & $61.8 \pm 13.7$ & $68.3 \pm 19.0$ & $63.5 \pm 18.2$ & $80.5 \pm 17.7$ & $64.9 \pm 27.2$ & $52.4 \pm 19.5$ & $53.5 \pm 26.3$ \\
\hline Italy & & $66.4 \pm 16.3$ & $65.9 \pm 14.1$ & $70.6 \pm 22.1$ & $75.8 \pm 22.7$ & $49.4 \pm 24.0$ & $53.4 \pm 24.5$ & $51.6 \pm 23.7$ \\
\hline
\end{tabular}




\section{DISCUSSION}

\subsection{The Croatian healthcare system}

Croatia developed its independent healthcare system after splitting with other ex-Yugoslav countries in 1991. The present healthcare system represents a Bismarck model (Varga, 2012). Both the financial and the human resources are scarce: the growing progress in diagnostics and therapy are costly, while patients' needs and rights have expanded. At the same time, accession to the EU has resulted in an export of qualified medical staff from Croatia to other countries.

Croatian Health Insurance Fund (CHIF) is the main healthcare insurer. The CHIF is subordinated to the Ministry of Health, although it has become financially independent approximately 3.5 years ago. Health insurance consists of mandatory health insurance and additional, voluntary health insurance. There are also other insurance companies, but the obligatory health insurance may be contracted only with the CHIF while the other insurance companies may only sell additional insurance as an add-on option. The healthcare providers' services are divided into three levels: primary, secondary and tertiary. Among the hospitals in Croatia there are 5 university hospital centers, 3 university hospitals, and 5 specialty university hospitals.

The Croatian healthcare system seeks to enhance the quality of healthcare services by introducing the national mandatory system of quality standards. The accreditation process of healthcare institutions is yet to be initiated. Certification is voluntary, basically by implementing the ISO quality management system. Results of the research on a sample of Croatian healthcare institutions at primary, secondary and tertiary levels indicate that there is generally insufficient knowledge and low implementation of the ISO quality management system in the healthcare system (Žabica, 2014).

There has been a growing interest in defining and measuring the quality of healthcare in Croatia, especially since the beginning of the 21st century. This has also resulted in a growing number of publications, either commenting or investigating the quality of national healthcare. A rising quality of these publications has also been noticed. There has been an increase in the number of both scientific publications targeting quality in healthcare or quality management (Lazibat 2007; 2009) and professional papers (Žabica, 2014), as well as preliminary reports (Ostojić, 2012).

However, there is still a lack of research and a gap in documented results regarding the healthcare professionals' attitudes about the safety climate. On the international level, research agencies, regulators, professional and other organizations have a positive attitude towards measuring healthcare professionals' attitudes regarding their work (Sexton, 2003). There is still a lack of metric to measure these attitudes and this is where SAQ steps in as a psychometrically sound survey instrument to assess the healthcare professional's attitudes, as these attitudes are referred to as climate or culture. When individual attitudes, defined as opinions, are aggregated, it represents a climate (Sexton, 2003). This is of particular interest when it comes to leadership and management in healthcare, as they are supposed to have a role in making decisions about resource 
allocation. A conclusion based on a validated questionnaire is needed for understanding and identifying areas which need improvement and for adequate allocation of resources.

\subsection{Aim of the study}

This study's aim was to cross-culturally validate the SAQ, in the form of the Croatian version, by investigating the perceptions of the safety climate among the management staff in the Croatian hospitals. To our knowledge, it is the first study to investigate this topic. The Croatian response rate was $80 \%$. Out of the 61 hospitals included, there were respondents from 49 hospitals that replied. The international benchmarking of response rate is $68 \%$ (Sexton, 2006). The response rate in the neighboring Italy was $60 \%$ (Ngyen, 2015), while in Albania, which has also developed its healthcare system from an entirely different former system, it was 70\% (Gabrani, 2015). However, we were not able to report a response rate on individual level and there was no need to identify the respondents by name (Sexton, 2003). Some of the participants in the study did not report the name of the hospital either. We were aware of this challenge beforehand, but accepted it since, to a certain extent, it guaranteed a higher response rate, as well as frank answers. This is why we divided hospitals into categories, to be able to match the answers with the pre-defined criteria, in order to make conclusions on the level of the categories.

The SAQ authors recommend hand-delivering the survey in order to obtain a higher response rate, although they anticipate different means of communication in the years ahead (Sexton, 2003). However, as almost a decade and a half has passed since, and this period has been characterized by a high intensity of IT implementation in healthcare, we decided to approach the participants by e-mail, with a link to a web-posted questionnaire. Also, for logistic reasons it was not possible for us to visit 61 hospitals across Croatia.

The Norwegian version of the questionnaire introduced a split of the questions on perceptions of management into two sets, one on hospital (top) management and one on local (unit) management, reformulating slightly the questionnaire's hypothesized factor structure by imagining two management perception factors instead of one, each containing one set of the five split questions on perceptions of management (Deilkås, 2008).

The findings of the Croatian SAQ are interesting also in terms of comparing with the results of Italian (Ngyen, 2015) and Albanian benchmarking data (Gabrani, 2015) regarding Perception of Management and Working Conditions.

\subsection{Validation of Croatian version of SAQ}

The results of our study using confirmatory factor analysis showed that the last two factors - Perception of Management and Working Conditions are structured as in the original US SAQ. We therefore recalculated all the factors by moving the Q29 from 
the Working Conditions factor to the Perception of Management factor. This was different from the published validation studies of SAQ that had been conducted in other European countries.

Internal consistency for the whole questionnaire was high but lower for two factors (Teamwork Climate and Safety Climate).

Internal consistency for these two factors can be significantly improved by letting out two questions (Q2 and Q11), both asking about the internal communication about the patients' safety. The reason why exactly these two questions affect the internal consistency might probably be explained by an explicit culture of strong hierarchy in the Croatian hospitals preventing open communication. Also, a no-blame culture has a long way to be fully developed and accepted among the healthcare staff.

Correlation between SAQ factors was comparable to that described in SAQ studies from other countries, out of which we chose Italy for its vicinity and culture similarities, Albania for its similar development and challenges of a recent healthcare system, and Brazil as a distant and entirely different country. The overall score was higher for most of the factors with the exception of Stress Recognition that was lower than in Brazil (Luiz, 2015) and Italy (Ngyen, 2015), but higher than in Albania (Gabrani, 2015). In Italy, where SAQ was tested on two hospitals, the stress recognition Cronbach's was 0.78 (Ngyen, 2015). In Albania, Cronbach's for Stress recognition was 0.62 and was not significantly related to any of the subscales (Gabrani, 2015). In Brazil, the Perceived stress mean was 64.9, and healthcare professionals with less than 6 months of experience perceived the acknowledgement of stressful factors better (Luiz, 2015).

\section{CONCLUSION}

As the study data were collected from most of the Croatian hospitals, it was possible to draw conclusions on the SAQ's external validity. Based on the data from the Croatian hospitals, we conclude that the Croatian version of the SAQ short form 2006 shows satisfactory internal psychometric properties.

The correlation between SAQ factors was comparable to that in other SAQ studies. Yet, the overall score in Croatia was higher for most of the factors, with the exception of Stress Recognition which was lower than in Brazil (Luiz, 2015) and in Italy (Ngyen, 2015), but higher than in Albania (Gabrani, 2015).

Along with the development of quality and safety in Croatian hospitals, future data on patient outcomes should allow for further validation studies, linking them with the SAQ scores. 


\section{REFERENCES:}

1. Alahmadi HA. Assessment of patient safety culture in Saudi Arabian hospitals. Qual Saf Health Care. 2010;9(17):1-5

2. Burr M, Sorra J, Nieva VF: Analysis of the Veterans Administration (VA) National Center for Patient Safety (NCPS) FY 2000 Patient Safety Questionnaire. Technical report. Westat: Rockville, MD; 2002. 2002, AHRQ Publication, AHRQ. Ref Type: ReportGoogle Scholar

3. Carthey J, de Leval MR, Reason JT: Institutional resilience in healthcare systems. Qual Saf Health Care. 2001, 10: 29-32. 10.1136/qhc.10.1.29.View ArticleGoogle Scholar

4. "Checklist for Assessing Institutional Resilience" (CAIR). [http://www.ihi.org/IHI/ Topics/PatientSafety/SafetyGeneral/Tools/ChecklistForAssessingInstitutionalResilience.htm]

5. Colla JB, Bracken AC, Kinney LM, Weeks WB: Measuring patient safety climate: a review of surveys. Qual Saf Health Care. 2005, 14: 364-6.

6. Deilkås ET, Hofoss D. Psychometric properties of the Norwegian version of the Safety Attitudes Questionnaire (SAQ), Generic version (Short Form 2006). BMC Health Services Research 2008; 8:191. DOI: 10.1186/1472-6963-8-191

7. Devriendt E, Van den Heede K, Coussement J, Dejaeger E, Surmont K, Heylen D, Schwendimann R, Sexton JB, Wellens NIH, Boonen S, Milisen K. Content validity and internal consistency of the Dutch translation of the Safety Attitudes Questionnaire: an observational study. Int J Nurs Stud. 2012;49:327-37. doi: 10.1016/j. ijnurstu.2011.10.002.

8. El-Jardali F, Dimassi H, Jamal D, Jaafar M, Hemadeh N. Predictors and outcomes of patient safety culture in hospitals. Qual Saf Health Care. 2011;11(45):4-12

9. European Society for Quality in Healthcare - Office for Quality Indicators: Use of Patient Safety Culture Instruments and Recommendations. ISBN 978-87-9937790-9 Copyright, March 2010 Olof Palmes Allé 13, DK-8200 Aarhus N, Denmark

10. Flin R, Burns C, Mearns K, Yule S, Robertson EM. Measuring safety climate in health care. Qual Saf Health Care 2006;15:109-115

11. Gabrani A, Hoxha A, Simaku A, Gabran J. Application of the Safety Attitudes Questionnaire (SAQ) in Albanian hospitals: a cross-sectional study. BMJ Open 2015;5:e006528. doi:10.1136/bmjopen-2014-006528

12. Hamdan M. Measuring safety culture in Palestinian neonatal intensive care units using the Safety Attitudes Questionnaire. J Crit Care. 2013;28:886. doi: 10.1016/j. jcrc.2013.06.002

13. Helmreich RL, Merritt AC, Sherman PJ, Gregorich SE, Wiener EL: The Flight Management Attitudes Questionnaire (FMAQ) NASA/UT/FAA Technical Report. 1993, Austin, TX, The University of Texas, 93-4. Ref Type: Report Google Scholar 
14. Hoffmann B, Domańska OM, Müller V, Gerlach FM. Developing a questionnaire to assess the safety climate in general practices (FraSiK): transcultural adaptation--a method report. ZEFQ. 2009;103:521-529.

15. Kaya S, Barsbay S, Karabulut E. The Turkish version of the safety attitudes questionnaire: psychometric properties and baseline data. Qual Saf Health Care. 2010;19:572-7.

16. Lazibat, T., Burčul, E., Baković, T. (2007). Primjena sustava za upravljanje kvalitetom u hrvatskom zdravstvu, Poslovna izvrsnost/Business Excellence, Vol. 1, No. 2: 31-43.

17. Lazibat, T. (2009). Upravljanje kvalitetom, Zagreb: Znanstvena knjiga

18. Lee, DH. Implementation of quality programs in health care organizations, Service Business. 2012; Vol. 6, No. 3: 387-404.

19. Lee, SM, Lee DH, Kang CY. The impact of high-performance work systems in the health-care industry: employee reactions, service quality, customer satisfaction, and customer loyalty, The Service Industries Journal. 2012; Vol. 32, No. 1:17-36.

20. Lee WC, Wung HY, Liao HH, Lo CM, Chang FL, Wang PC. Hospital safety culture in Taiwan: a nationwide survey using Chinese version safety attitude questionnaire. BMC Health Serv Res. 2010;10:1-8.

21. Luiz RB, Simões AL, Barichello E, Barbosa MH. Factors associated with the patient safety climate at a teaching hospital. Rev Lat Am Enfermagem. 2015 SepOct;23(5):880-7.

22. Manchester Patient Safety Framework (MaPSaF). [http://www.npsa.nhs.uk/patientsafety/improvingpatientsafety/humanfactors/mapsaf/]

23. Nieva VF, Sorra J. Safety culture assessment: a tool for improving patient safety in healthcare organizations. Qual Saf Health Care. 2003;2(Suppl 2):17-23.

24. Nguyen G, Gambashidze N, Ilyas SA, Pascu D. Validation of the safety attitudes questionnaire (short form 2006) in Italian in hospitals in the northeast of Italy. BMC Health Services research (2015), 15:284.

25. Ostojić R, Bilas V, Franc S. Unapređenje kvalitete zdravstvenih sustava zemalja članica Europske Unije i Republike Hrvatske. Poslovna izvrsnost/Business Excellence, Zagreb 2012; 2: 109-25.

26. Pronovost $\mathrm{P}$, Sexton B. Assessing safety culture: guidelines and recommendations. Editorial. Qual Saf Health Care 2005;14:231-3.

27. Pronovost PJ, Berenholtz SM, Goeschel CA, Needham DM, Sexton JB, Thompson DA, et al: Creating High Reliability in Health Care Organizations. Health Serv Res. 2006, 41: 1599-1617. 10.1111/j.1475-6773.2006.00567.x.View ArticlePubMedPubMed CentralGoogle Scholar.

28. Pronovost PM, Weast BM, Rosenstein BM, Sexton JBP, Holzmueller CGB, Paine LM, et al: Implementing and Validating a Comprehensive Unit-Based Safety Pro- 
gram. Journal of Patient Safety. 2005, 1: 33-40. 10.1097/01209203-200503000-00008. View ArticleGoogle Scholar.

29. Sexton JB, Helmreich RL, Neilands TB, Rowan K, Vella K, Boyden J. The Safety Attitudes Questionnaire: psychometric properties, benchmarking data, and emerging research. BMC Health Serv Res. 2006;44(6):1-10

30. Sexton JB, Thomas EJ, Helmreich RL, Neilands TB, Rowan K, Vella K, et al: Frontline Assessments of Healthcare Culture: Safety Attitudes Questionnaire Norms and Psychometric properties. Technical report 04-01. 2004, 1-12-12-2007. Ref Type: Report, [http://www.utpatientsafety.org]Google Scholar

31. Sexton JB, Thomas EJ, Helmreich RL: Error, stress, and teamwork in medicine and aviation: cross sectional surveys. BMJ. 2000, 320: 745-749. 10.1136/bmj.320.7237.745. View ArticlePubMedPubMed CentralGoogle Scholar

32. Sexton JB, Thomas EJ, Grillo SP. The safety attitudes questionnaire (SAQ) Guidelines for administration. The University of Texas Center of Excellence for Patient Safety Research and Practice; Technical Report. Sponsored by the Agency for Healthcare Research and Quality, January 11, 2003

33. Sorra JSNV. Hospital Survey on Patient Safety Culture. Rockville, MD, Agency for Healthcare Research and Quality. 2004, AHRQ Publication 41[04], Ref Type: ReportGoogle Scholar

34. Sperber AD. Translation and validation of study instruments for cross-cultural research. Gastroenterology. 2004, 126: S124-S128.

35. Varga S. Sustav kvalitete u zdravstvu. Available at: http://www.zzjzfbih.ba/wp-content/uploads/2012/11/Varga_Sinisa.pdf.

36. Weingart SN, Farbstein K, Davis RB, Phillips RS: Using a multihospital survey to examine the safety culture. Joint Commission Journal on Quality and Safety. 2004, 30: 125-132.PubMedGoogle Scholar

37. Žabica S., Lazibat T., Dužević I. Implementacija sustava upravljanja kvalitetom na različitim razinama zdravstvene djelatnosti. Poslovna izvrsnost, Zagreb, God. VIII (2014) Br. 1, 9-24. 


\section{APPENDIX}

\section{Croatian translation of the SAQ short form 2006}

1. U ovoj jedinici cijeni se doprinos medicinskih sestara.

2. U ovoj je jedinici teško progovoriti o uočenom problemu skrbi za pacijenta.

3. Nesporazumi se u ovoj jedinici rješavaju na primjeren način (tj. ne TKO je u pravu, nego ŠTO je najbolje za bolesnika)

4. U skrbi za bolesnike imam potrebnu podršku ostalog osoblja.

5. Zaposlenici mogu lako postavljati pitanja kad nešto ne razumiju.

6. Liječnici i sestre ovdje rade kao dobro koordinirani tim.

7. Kao pacijent ovdje bih se osjećala/osjećao sigurno.

8. U ovoj jedinici pogreške liječenja se primjereno rješavaju.

9. Poznati su mi putovi za postavljanje pitanja o sigurnosti bolesnika u ovoj jedinici.

10. Dobivam odgovarajuće povratne informacije o mojem radu (učinku).

11. U ovoj jedinici teško je raspravljati o pogreškama.

12. Moji me kolege potiču da izvijestim o mogućoj ugrozi sigurnosti bolesnika.

13. Kultura u ovoj jedinici olakšava učenje iz grešaka drugih.

14. Rukovodstvo bi prihvatilo moje moguće prijedloge o sigurnosti.

15. Volim svoj posao.

16. Raditi ovdje je kao da sam dio velike obitelji.

17. Ovo je dobro mjesto za rad.

18. Ponosna/ponosan sam što radim u ovoj jedinici.

19. Moral u ovoj jedinici je visok.

20. Kada mi radno opterećenje postane preveliko, moj se učinak smanji.

21. Kada sam umoran/a, manje sam djelotvoran/a.

22. Vjerojatnije je da ću griješiti u napetim ili neprijateljskim situacijama.

23. Umor utječe na moj učinak u hitnim situacijama (npr. oživljavanje, napadaj).

24. Rukovoditelji podržavaju moj svakodnevni trud.

25. Rukovoditelji ne ugrožavaju svjesno sigurnost pacijenata.

26. Rukovoditelji rade dobro.

27. S problematičnim osobljem konstruktivno se postupa. 
28. Dobivam pravodobne i potrebne informacije o događajima koji bi mogli utjecati na moj rad.

29. Broj zaposlenika u ovoj jedinici dovoljan je za broj bolesnika.

30. Ova bolnica dobro provodi edukaciju novih zaposlenika.

31. Redovito su mi dostupne potrebne informacije za odluke u dijagnostici i terapiji.

32. Pripravnici u ovoj jedinici imaju odgovarajući nadzor.

33. Suradnja s medicinskim sestrama u ovoj jedinici je dobra.

34. Suradnja s liječnicima u ovoj jedinici je dobra.

35. Suradnja s farmaceutima u ovoj jedinici je dobra.

36. Česti su prekidi komunikacije koji dovode do kašnjenja u skrbi za bolesnika.

Zanimanje

Veličina bolnice:

Radim u (jedinica u kojoj obavljate najveći dio radnog vremena):

Spol

Godine na ovom poslu

Imam formalnu edukaciju iz upravljanja/rukovođenja u zdravstvu:

Međunarodni sustav upravljanja kvalitetom (SUK) u ovoj bolnici:

Uspostava međunarodnog sustava upravljanja kvalitetom (SUK) u bolnicama snižava trošak poslovanja:

Bolnica u kojoj ste zaposleni (odgovor nije obvezan, iako je podatak zajamčeno tajan i znatno doprinosi vrijednosti istraživanja) 


\title{
VALIDACIJA UPITNIKA SAFETY ATTITUDES QUESTIONNAIRE 2006 (KRATKI OBLIK) KOD MENADŽMENTA HRVATSKIH BOLNICA
}

\author{
Maša Bulajić ${ }^{4}$, Tonći Lazibat $^{5}$ \& Davor Plavec ${ }^{6}$
}

\section{Sažetak}

Većina zdravstvenih ustanova nema mogućnosti objektivne procjene sigurnosti skrbi koju pružaju svojim pacijentima. Klima ili ozračje sigurnosti može se tumačiti kao onaj dio kulture sigurnosti koji se može izmjeriti.

Percepcija zdravstvenih djelatnika o ozračju sigurnosti koristi se kao alat za razvoj instrumenata mjerenja ozračja sigurnosti pacijenata u zdravstvenom sustavu. Safety Attitudes Questionnaire 2006 Short Form (SAQ) smatra se pouzdanim i osjetljivim alatom za procjenu stavova o sigurnosti. Koristi se za istraživanje povezanosti rezultata ozračja sigurnosti ishoda po pacijenta, te predstavlja najčešće korišteni psihometrijski upitnik za mjerenje stavova u djelatnika koji su u praksi.

Dokazano je da SAQ posjeduje dobre psihometrijske karakteristike i nakon prevođenja na druge jezike. Ovo je na SAQ temeljeno, on-line, nacionalno, presječno (cross-sectional) anketno istraživanje stavova o sigurnosti bolničkih rukovoditelja u Republici Hrvatskoj. Cilj je istraživanja validirati SAQ preveden na hrvatski jezik vrednovanjem psihometrijskih obilježja upitnika na uzorku osoblja zaposlenog na rukovodećim radnim mjestima u hrvatskim bolnicama.

Međusobna povezanost SAQ faktora usporediva je sa SAQ istraživanjima provedenima u drugim državama. Međutim, sveukupni je rezultat u Hrvatskoj viši za većinu faktora, s izuzetkom prepoznavanja stresa. Paralelno s razvojem kvalitete i sigurnosti u hrvatskim bolnicama, u budućnosti dostupni podaci trebali bi omogućiti daljnja validacijska istraživanja, povezujući ih s rezultatima SAQ-a.

Ključne riječi: Hrvatska; rukovoditelji, bolnički; Safety Attitude Questionnaire (SAQ); sigurnost; stav.

JEL klasifikacija: I11, I18

\footnotetext{
${ }^{4}$ Maša Bulajić, dr.med., mr.sc.econ / Doktorand, Marti Farm LLC., Zagreb, Hrvatska, E-mail: merkur3005@ gmail.com

5 Dr. sc. Tonći Lazibat, redoviti profesor u trajnom zvanju, Ekonomski fakultet - Zagreb, Sveučilište u Zagrebu, Hrvatska, E-mail: tlazibat@efzg.hr

${ }^{6}$ Dr. sc. Davor Plavec, izvanredni profesor, Medicinski fakultet, Sveučilište Josipa Jurja Strossmayera u Osijeku, Osijek, Hrvatska, E-mail: plavec@bolnica-srebrnjak.hr
} 